\title{
SUSTAINABLE DEVELOPMENT AND TOURISM (EXPERIENCE OF EUROPEAN COUNTRIES)
}

\begin{abstract}
Аннотация. Рассмотрен опыт европейских стран по предоставлению туристических услуг на основе принципов устойчивого развития.

Ключевые слова: устойчивое развитие, туризм.

Abstract. The article deals with experience of european countries in supply of tourism services based on principle of sustainable developement.

Keywords: sustainable developpement, tourism.
\end{abstract}

Одним из фракторов, способствующих устойчивому региональному развитию, является туризм. В настоящее время спрос на турпродукты имеет тенденцию к росту. Однако увеличение турпотока имеет негативные последствия, связанные с нарушением экосистемы [1]. Особенно эта проблема актуальна для регионов, которые развивают экологический и этнотуризм или имеют на своей территории объекты, привлекательные для туристов с точки зрения своей уникальности в плане природного наследия. Поэтому развивая туристические направления, в данных регионах необходимо придерживаться принципов устойчивого развития.

В этой связи интересным и полезным является опыт зарубежных стран, где концепции устойчивого развития территории придерживаются уже давно и уже имеют определенные успехи. В первую очередь, это страны Евросоюза, где принципы устойчивого развития обусловлены требованием EC [2].

Страной, которая одной из первых приняла принципы устойчивого развития, является Германия [4]. В Германии основы устойчивого развития реализуют в таких видах туризма, как сельский и событийный туризм, что выражается в организации туристической деятельности таким образом, что сохраняются традиционные ландшафты, ремесла, традиционная архитектура населенных пунктов (в первую очередь сельских).

В Италии на государственном уровне идеи устойчивого развития стали реализовывать с 2007 года [3]. В сфрере туризма данная концепция нашла отражение в оздоровительном и гастрономическом туризме.

Во Франции предоставление туристических услуг (сельский туризм, экотуризм, гастрономические и винные туры) организуется таким образом, чтобы сохранить традиционный облик населенных пунктов и природное биоразнообразие, регулируется влияние человека на окружающую среду, 
осуществляется управление турпотоками, привлекается внимание туристов к проблемам окружающей среды.

В Испании принципы устойчивого развития реализуются в сельском туризме и экотуризме (уход за животными, гастрономические туры, проживание на фрермах).

Польша и Венгрия приняли стратегию устойчивого развития не так давно (в 2006 и 2007 годах соответственно [3]). В сорере туризма она находит отражение в сельском и спортивном туризме (охота, рыбалка), что приносит значительный экономический доход этим странам.

В Беларуси, которая членом Евросоюза не является, в настоящее время реализуется проект «Поддержка устойчивого развития туризма в Беларуси» (финансируется Европейским союзом). Проект помогает реализовать передовые практики устойчивого развития туризма в таких его видах, как этноэкологический, сельский и спортивный туризм (охота, рыбалка).

Организуя предоставление турпродукта на основе концепции устойчивого развития, европейские страны не только развивают территорию, зарабатывая при этом денежные средства, но и сохраняют свое природное достояние.

В России при организации туристической деятельности используют отдельные принципы концепции устойчивого развития, но нет государственной программы по устойчивому развитию туризма в РФ.

Использование опыта осуществления туристической деятельности зарубежных стран на основе принципов устойчивого развития будет способствовать не только развитию туристической отрасли, но и переходу территорий на модель устойчивого регионального развития.

\section{ЛИТЕРАТУРА}

1. Даниленко Н.Н. Туризм и устойчивое развитие региона: социальный и институциональный аспекты / Н.Н. Даниленко, Н.В. Рубцова. Иркутск: Изд-во БГУЭП, 2013. 158 с.

2. Сеселкин А.И. Устойчивое развитие туризма как приоритетное направление деятельности Всемирной туристской организации: постановка проблемы исследования / А.И. Сеселкин // Вестник РМАТ. 2014. № 1 (10). С. 914.

3. Синякова А.Ф. Опыт ряда европейских стран в разработке национальной стратегии устойчивого развития / А.Ф. Синякова // Бюллетень «На пути к устойчивому развитию России». 2013. № 63. С. 71-78.

4. Опыт Германии по развитию туризма на сельских территориях. URL: http://agrardialog.ru (дата обращения: 02.03.2018). 